\title{
Els eixams de meduses i la salut del mar
}

\author{
Josep-Maria Gili \\ Institut de Ciències del Mar (CSIC), Barcelona
}

Com cada any, també aquest estiu han aparegut meduses a les nostres platges. Un fenomen que anys enrere es produïa de tant en tant ara s'ha tornat molt més freqüent. La seva convivència amb els banyistes ja s'ha fet habitual, però no deixa de resultar problemàtica i causa de molts disgustos. Hi ha alguna solució?

\section{Un perill amagat en el museu}

Fa uns anys, en una institució científica francesa es va produir un incident sorprenent. Hi tenien emmagatzemats centenars d'espècimens animals en dissolucions d'alcohol etílic del $70 \%$. Com que feia anys que les hi tenien, suposaven que el lent minvar del nivell del líquid es podia atribuir a l'evaporació.

Però un dia un vigilant inexplicablement va entrar en coma. I no es tractava d'un coma etílic, com algú podria suposar.

Va resultar que, afeccionat a l'alcohol com era, efectivament era el responsable del lent descens del nivell de líquid dels flascons durant anys sense més problemes. Però tot va canviar quan va tastar l'alcohol d'un recipient que contenia una medusa des de feia ben bé cinquanta anys. Tants anys després de morir, les seves cèl-lules urticants encara eren capaces de disparar-se i d'injectar en les parets de l'estómac del malaventurat vigilant una quantitat de verí que per ben poc no li va costar la vida. Com és possible, això?

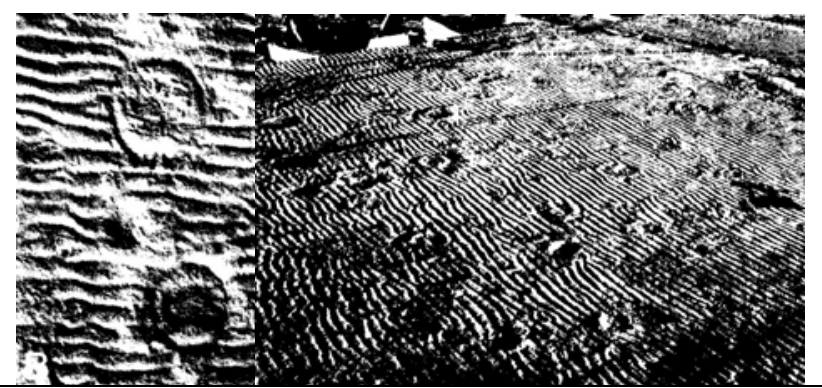

Figura 1. Fòssils de meduses a Wisconsin (EUA), d'una antiguitat d'uns 500 milions d'anys (finals del càmbric). (Fotos: J.D. Hagadom).

\section{Les meduses, animals primitius}

Entre els organismes actuals, les meduses són dels organismes més antics. Ja n'hi havia fa més de 500 milions d'anys (fig. 1). Tot i ser organismes força simples (fig. 2), disposen d'un dels verins més potents del regne animal: una mescla complexa de polipèptids i enzims.

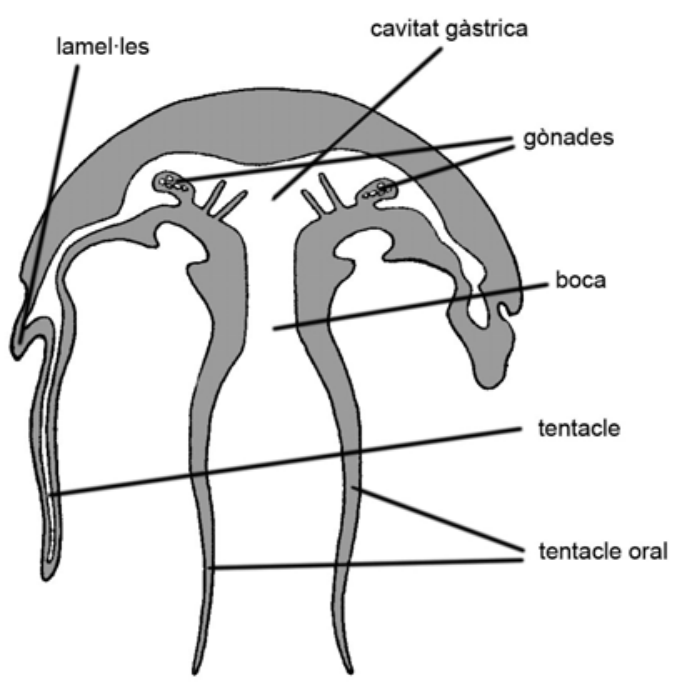

Figura 2. Diagrama d'una medusa.

Les cèl.lules urticants estan distribuïdes per tota la seva superfície corporal, però més concentrades en els tentacles (de $10^{5}$ a $10^{6}$ per $\mathrm{cm}^{2}$ ). Per això els depredadors les ataquen pel damunt, aprofitant també que la part superior conté més matèria orgànica. Tinguem en compte que tenen més d'un 95\% d'aigua en el cos, i per això tenen una densitat 
molt semblant a la de l'aigua del mar, permetent que hi puguin flotar.

El verí l'injecten les cèl-lules urticants, anomenades cnidòcits, (fig. 3) mitjançant uns dispositius anomenats nematocists que es disparen rapidíssimament.

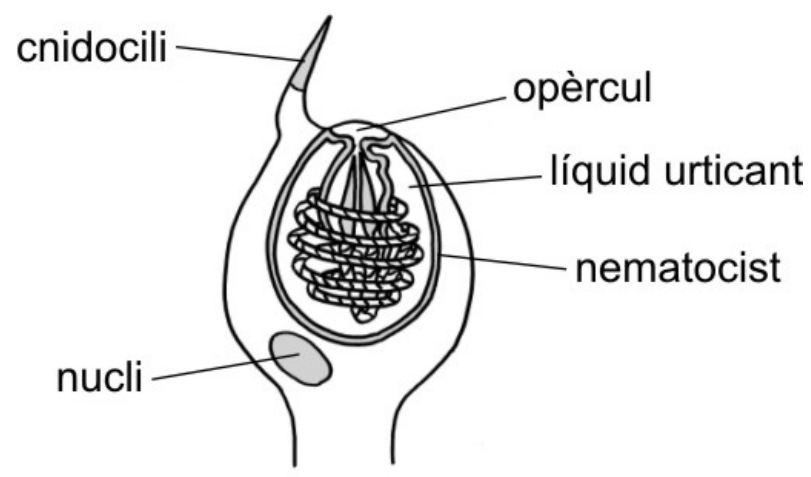

Figura 3. Diagrama d'un cnidòcit o cnidoblast, la cèl-lula urticant d'una medusa.

Només passen 3 mil.lisegons des del moment que s'activen -per contacte, per canvi de temperatura o per canvi de salinitat-, s'obre l'opèrcul i es dispara un filament a gran velocitat que inocula el verí sota la pell de la víctima (fig 4) al mateix temps que una sèrie de dents fixen el nematocist a la pell $i$ així eviten el seu retrocés.

S'ha comprovat que si tot va tan ràpid és perquè la pressió del líquid urticant dins del nematocist és d'unes dues-centes atmosferes!

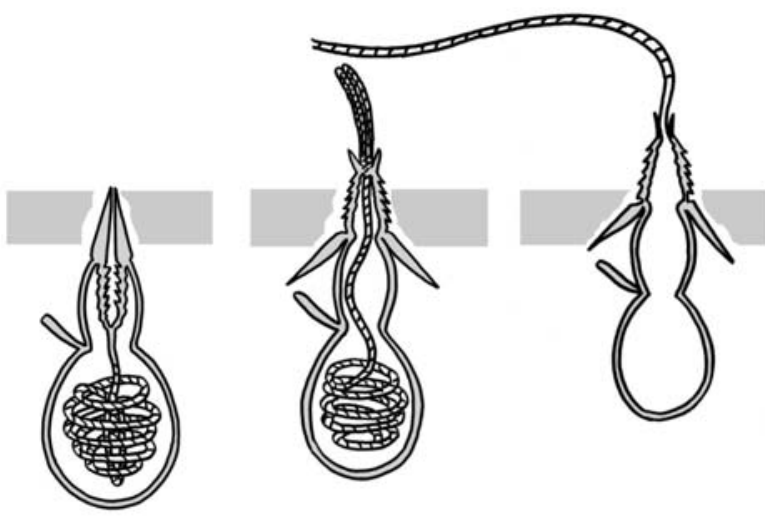

Figura 4. Nematocist en procés de disparar-se i injectar el verí. La zona grisa representa la part superficial de la pell de la víctima.

Com hem vist en la història del vigilant bevedor, els nematocists mantenen la seva capacitat d'inocular el verí molts anys després de la mort dels cnidòcits, les cèl-lules que els contenen. Però cal dir que els restes de meduses que de vegades s'acumulen a les platges, perden ràpidament la capa- citat de disparar-se, a l'haver-se deshidratat exposades al sol. A més, tant la calor com el fred fan que el verí perdi les seves propietats.

\section{En cas de picada de medusa}

La picada d'una medusa sobre petits organismes marins els anestesia o els mata, facilitant que se'ls pugui portar a la boca mitjançant els tentacles. En el cas de persones la picada sol ser força dolorosa, semblant a la d'una cremada (fig. 5). (Per sort per a nosaltres, les espècies de meduses que produeixen picades mortals a les persones en aigües tropicals no són les que trobem a les nostres platges. Per exemple, a Austràlia cada any causen més morts que els taurons).

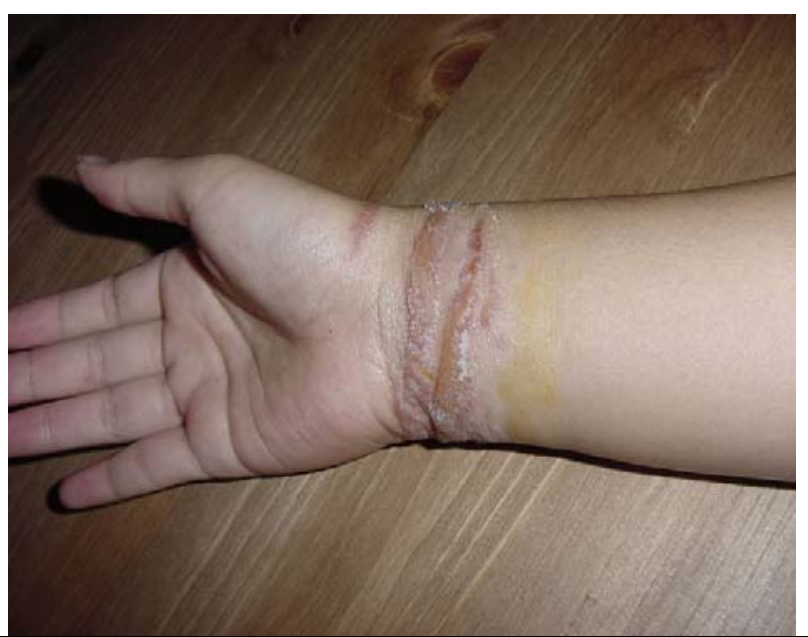

Figura 5. Efectes d'una picada de medusa. (Foto: Romi Ichikawa).

Un cop produïda la picada és imprescindible actuar-hi correctament si no es vol empitjorar les coses.

Utilitzant pinces caldrà treure primerament les restes del tentacle, si són visibles.

Atès que poden haver quedat a la pell cèl.lules sense esclatar, cal resistir la tendència natural a gratar-se o a eixugar-se amb una tovallola, ja que això els dispararia i alliberaria encara més verí.

El mateix es pot dir de l'aigua dolça: el canvi de salinitat també els pot fer esclatar. Per tant, caldrà rentar la pell amb aigua salada per fer caure els nematocists que encara són actius, mai amb aigua dolça.

Malgrat el que es diu, el vinagre no soluciona res en la majoria de casos. Només en una sola espècie, l'anomenada caravel.la portuguesa (Physalia physalis, fig. 6) és indicat posar vinagre en la zona afectada. (De totes maneres, al tenir unes cèl-lules urticants molt grans, les seves picades poden deixar l'afectat en coma: cal fugir-ne sempre! No és una espècie habitual a les nostres costes sinó al 
nord d'Àfrica, però amb l'escalfament global és previsible que vagin arribant aquí).

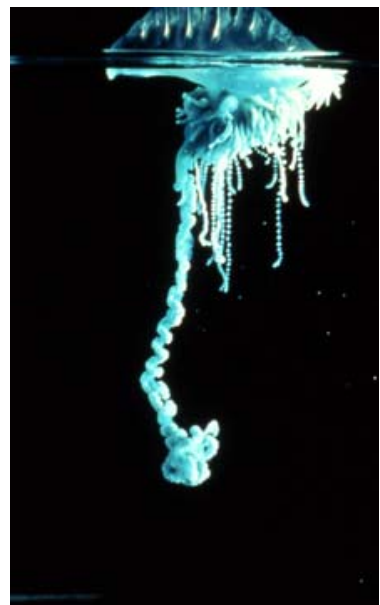

Figura 6. Caravel-la portuguesa (Physalia physalis). (Foto: Claude Carré).

Una altra mesura serà posar sobre la picada una bossa de plàstic que contingui glaçons durant uns cinc o deu minuts. El fred desnaturalitza les proteïnes del verí i el fa innocu.

Finalment, tal com mostra la figura 4 cada inoculació ha produiit una ferida a la pell, una via oberta a les infeccions. Per prevenir-les s'hi pot posar algun antisèptic, com tintura de iode, tres o quatre vegades al dia durant dos o tres dies.

Fins aquí el que són els casos més comuns. Però cal saber que hi pot haver complicacions.

La primera és que una picada de medusa aporta toxines que sensibilitzen el cos. Per això, una persona que rebi una segona picada corre un perill més elevat de reacció exagerada (xoc anafilàctic), que pot arribar a causar problemes molt greus.

Donada l'elevada toxicitat del verí cal evitar de totes totes que les toxines arribin al torrent sanguini, ja que al ser neurotòxiques i cardiotòxiques poden causar problemes cardíacs, respiratoris, neurològics, circulatoris... Conseqüentment, les persones amb problemes seriosos d'aquesta mena haurien d'evitar exposar-se a picades de meduses.

Perquè no arribi el tòxic al torrent sanguini cal tenir especial cura en els casos de picada on la pell és més fina, com les axil.les. En el cos dels infants el problema de les picades és relativament més important que en un adult al disposar de més superfície corporal per quilogram de massa.

\section{Mesures preventives}

Per evitar tots aquests problemes el millor és prevenir les picades. La primera mesura és no tocar mai les meduses, encara que estiguin mortes: ja hem vist com el perill no s'acaba amb la mort de l'animal.

No ens hem de banyar si es veuen meduses o si ho demanen els serveis de vigilància de la platja. En aquests casos no és que ataquin, sinó que cal evitar el contacte tant amb les meduses com amb fragments seus, visibles o no. Caldrà anar també amb compte amb la zona on trenquen les onades, ja que s'hi poden acumular restes de meduses. Per tant, si hi ha perill, tothom fora de l'aigua.

Una altra mesura preventiva molt eficaç és utilitzar crema solar o cobrir el cos amb roba lleugera, com samarretes.

\section{Ha augmentat la presència de meduses a les nostres platges?}

Hi ha molts estudis que confirmen l'augment de la presència de meduses a les platges de diversos indrets de tot el món, des d'Alaska a Austràlia, del Japó a Namíbia o de Mèxic a l'Atlàntic Nord.

A casa nostra les dades també van en la mateixa direcció. Vegeu, per exemple (fig. 7) l'augment del percentatge de casos de picades de meduses atesos pels serveis de la Creu Roja a Barcelona. (La disminució de l'any 2000 es pot explicar per la disminució en l'ús de la platja a causa del mal temps).

Es tracta, doncs, d'un fenomen mundial. Això ja fa preveure que no serà de fàcil solució.

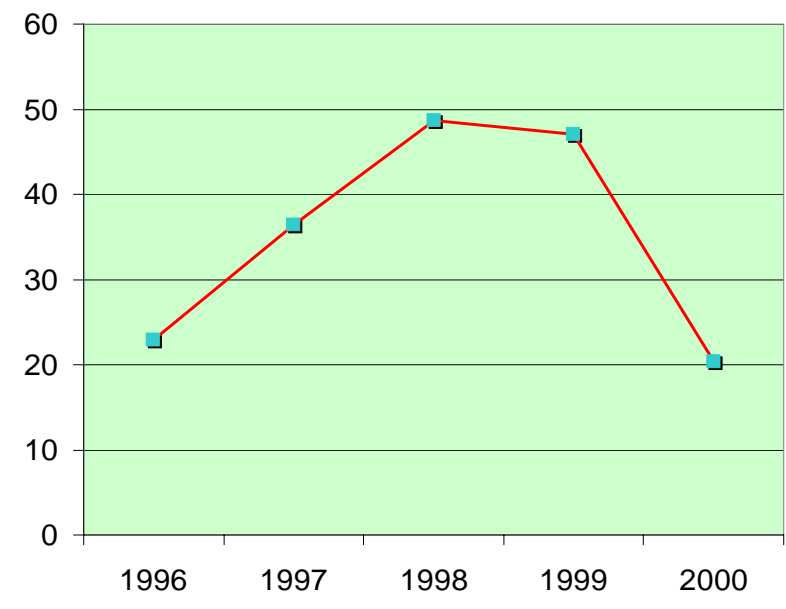

Figura 7. Evolució del percentatge de les actuacions de la Creu Roja a les platges del municipi de Barcelona que corresponien a picades de medusa. (Creu Roja, 2000)

\section{Què és el que causa aquest problema?}

L'augment dels problemes amb meduses a les platges es correspon també amb un augment en 
les poblacions d'aquestes espècies. Les causes d'aquests dos fenòmens relacionats són diverses. Vegem-ne les més importants.

\section{Sobrepesca}

Els depredadors de les meduses són sobretot peixos com les tonyines i peixos espasa, així com les tortugues marines.

L'excés de pesca que es produeix a tot el món disminueix contínuament les poblacions de peixos, al ser més intensa que el ritme de reposició de les espècies.

Les tortugues, que fa dos-cents anys eren molt nombroses a les nostres costes, ara cada vegada són més escasses i tenen més problemes per reproduir-se: en favor del turisme han estat desplaçades de les platges que utilitzaven per fer-ho. Per altra banda, els plàstics flotant en el mar els confonen amb meduses i se'ls empassen però no els poden digerir, cosa que bloqueja el seu tub digestiu i les condemna a morir d'inanició.

Al disminuir contínuament les poblacions de depredadors no és estrany que les de meduses augmentin.

Les meduses solen fer vida a certa fondària durant el dia a la zona final de la plataforma continental, a unes 10 o 20 milles de la costa. A la nit pugen cap a la superfície a alimentar-se del zooplàncton (són carnívores) amb l'avantatge de no ser vistes pels depredadors. Però molts peixos fan les postes al fons marí i les meduses ho aprofiten per alimentar-se dels peixos juvenils. Si l'excés de pesca origina un augment de meduses, aquest provoca encara una minva més gran en la població de peixos i en la pesca.

En un estudi realitzat al banc de pesca de Namíbia, freqüentat per la flota espanyola, es constata que actualment hi ha una massa de lluç de 3,5 milions de tones... mentre que la de meduses és de 12 milions. Fa vint anys, per cada quilo de medusa n'hi havia 10 de peix. Les meduses tendeixen a ocupar el lloc del peixos a les cadenes tròfiques.

\section{Canvi del règim de pluges}

Les meduses viuen i es reprodueixen normalment mar endins, on troben condicions més estables i favorables que a la costa. Es desplacen lentament: nedant poden arribar només a uns 55 metres per hora. Si arriben a la platja és sobretot perquè són empeses pels corrents.

Ara bé. En sèries llargues de dades en el Mediterrani s'ha observat que les meduses apareixien a les platges aproximadament en períodes d'uns dotze anys. Llavors se les hi observava durant dos o tres anys seguits i no tornaven fins a l'inici d'un altre període. Curiosament, aquests dos o tres anys $\mathrm{amb}$ meduses coincidien amb anys especialment eixuts, de pluges minses. Quina relació hi ha entre una cosa i l'altra?

En condicions de pluges normals les aigües costaneres són més dolces, menys denses que les aigües exteriors. Aquestes, degut a la insolació són més calentes que les de la costa, refredades per les aportacions d'aigües continentals i per les brises costaneres. Aquestes dues masses d'aigua, de diferent salinitat i temperatura, són difícils de barrejar i es mantenen separades (fig. 8). Les meduses, que viuen mar endins, es queden, doncs, lluny de la costa.

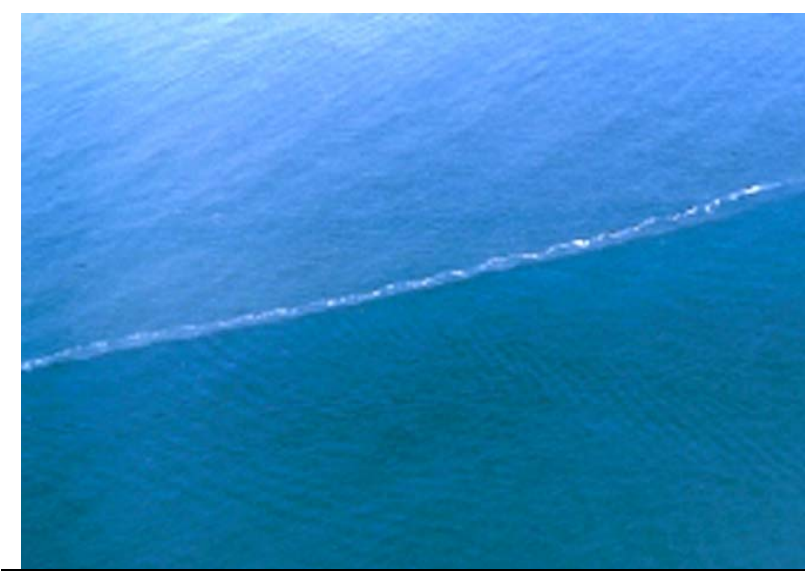

Figura 8. Front de contacte entre les dues masses d'aigua de propietats diferents. (Foto: Francesc Pagès)

En canvi, en els anys poc plujosos l'aigua costanera no és ni tan dolça ni tan freda. Les seves característiques són més semblants a les de les aigües exteriors i l'aiguabarreig ja és possible. Les meduses ara sí que poden arribar a la costa.

La periodicitat entre els episodis de meduses a la costa ha desaparegut. Més aviat és al contrari: cada any n'hi ha i alguns anys, excepcionalment, no.

La causa de tot això és el canvi climàtic, que al produir una disminució de les pluges en el nostre país ha originat aquest fenomen.

\section{Eutrofització d'ecosistemes costaners}

Al Mar Menor, una llacuna hipersalina, hi havia meduses coexistint sense problemes amb el cultiu del mol-lusc. Però els canvis antropogènics d'unes dècades ençà han estat constants: abocament de residus miners, construcció de la Mànega, augment del cabal d'aigües fertilitzades procedents de regadius, acumulació d'un milió de persones al seu entorn durant l'estiu...

Però l'ampliació de la connexió amb el Mediterrani amb la finalitat de facilitar la navegació va permetre l'entrada d'espècies d'altres espècies de meduses i la disminució de la salinitat. Dues espè- 
cies alòctones de meduses van proliferar amb un èxit desmesurat i s'han convertit en un problema important.

Instal-lar xarxes protectores a les platges per impedir la seva arribada (una mesura força discutible ja que perjudica altres espècies i no assegura que no hi puguin passar fragments de tentacles) 0 pescar-les amb vaixells suposa anualment un cost d'un milió d'euros.

L'any 2000 s'hi van recollir 2000 tones de meduses, massa corresponent a uns sis milions d'individus.

Fenòmens semblants d'eutrofització provoquen grans eixams de meduses també en altres zones del món, com als fiords noruecs, a l'Adriàtic, al Mar de Nord...

\section{Contaminació per hidrocarburs}

En alguns casos s'ha observat un augment de meduses en zones afectades per vessament de petroli, com a Alaska (fig. 9) i al Golf de Mèxic.

S'especula que la raó podria ser que els bacteris marins, alguns dels quals són utilitzats per combatre les marees negres, proliferen en aigües contaminades per hidrocarburs. Constituirien l'inici d'una cadena tròfica que passaria per protists heteròtrofs i arribaria a les meduses. Paradoxalment sembla que el petroli que cau al mar acaba alimentant indirectament les meduses.

\section{I les solucions?}

Com hem pogut veure, trobar meduses a les platges és ja un problema mundial. No té cap solució fàcil, però sí que es poden organitzar algunes mesures pal-liatives, amb un cost econòmic notable.

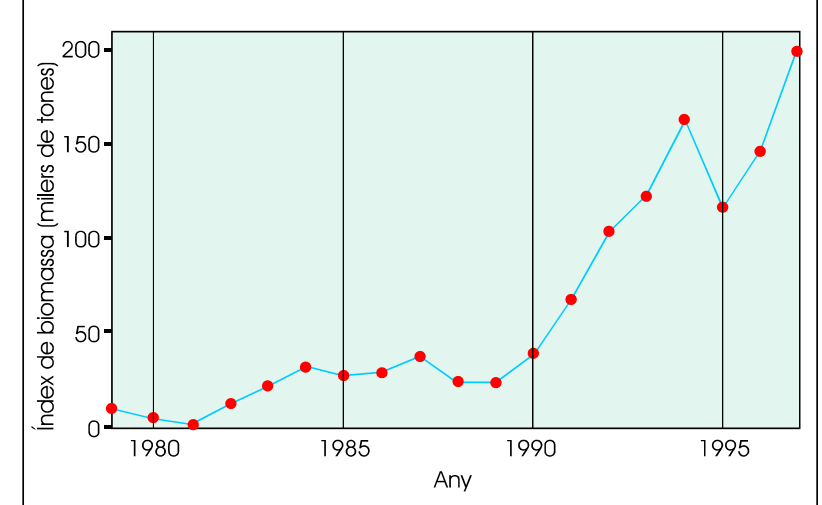

Figura 9. Evolució de la biomassa de meduses al mar de Bering. La catàstrofe del petroler Exxon Valdez es produí a Alaska el 1989.

Es podria modelitzar el moviment dels eixams de meduses a partir dels corrents marins i del vent per ajudar a localitzar-los. La informació procedent de tota mena d'embarcacions caldria poder-la organitzar. Un cop situats els grans eixams es podrien pescar les meduses a mar obert, intentant de no perjudicar altres comunitats. Prop de les platges es podrien utilitzar embarcacions tipus pelicà.

Però també hauríem d'anar repensant seriosament la nostra manera de tractar la naturalesa.

\section{Bibliografia}

Creu Roja de Catalunya (2000). Platges 2000 Barcelona. Informe memòria.

Gili, J.M. i Pagès, F. (2005). Les proliferacions de meduses. Boll. Soc. Hist. Nat. Balears, 48, 9-22. 